\title{
Comércio Trade
}

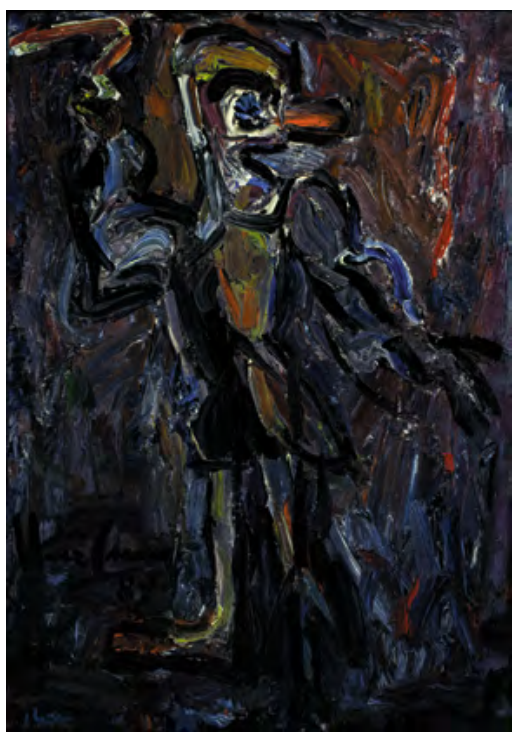

Palhaço, 1987

Clown

Iberê Camargo 


\section{Trade}

\section{Geisa Daise Gumiero Cleps ${ }^{1}$}

Going shopping is a regular activity in people's lives. Virtually all the goods needed for survival are purchased. That apparently simple fact has great significance, since it characterizes our contemporary society to which the generalization of consumption is a fundamental aspect in the constitution of the economy and in the reorganization of the geographic space.

The analysis of commercial activities leads to the understanding of social relations, the living space in the everyday circumstances of cities. In History, the birth of the city precedes that of markets, since the latter came as a consequence of the social and territorial division of labor and of the formation of surpluses. These events have made possible the emergence of a place for exchanges and the intraurban organization of cities.

As cities expanded, new places of attraction for the reproduction of commercial capital were created and incorporated by the space producing agents, resulting in the advent of new urban centralities and in the concentration of tertiary equipment.

In the contemporary society, consuming has become an everyday action marked by the acquisition of goods that aim at the satisfaction of the population's needs, which can be either basic ones for survival or others created by means of communication and information.

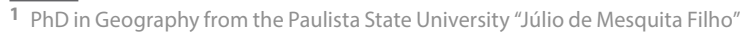
(Unesp) and Associate Professor at the Federal University of Uberlândia. 


\section{Comércio}

\section{Geisa Daise Gumiero Cleps ${ }^{1}$}

Fazer compras é algo bastante comum na vida das pessoas. Praticamente todos os bens necessários à sobrevivência são comprados. Esse fato de aparência simples tem grande significado, caracteriza a sociedade contemporânea na qual a generalização do consumo representa aspecto de fundamental importância na constituição da economia e na reorganização do espaço geográfico.

A análise das atividades comerciais permite compreender as relações sociais, o espaço de vida no cotidiano das cidades. Na história, a cidade precede a origem dos mercados, os quais surgiram a partir da divisão social e territorial do trabalho e da formação de excedente. Estes acontecimentos possibilitam o surgimento do lugar das trocas e a organização intraurbana das cidades.

À medida que as cidades se expandiam, novos lugares de atração para a reprodução do capital comercial foram criados e incorporados pelos agentes produtores do espaço, possibilitando o surgimento de novas centralidades urbanas e de concentração dos equipamentos terciários.

Na sociedade contemporânea, consumir tornou-se um ato cotidiano marcado pela aquisição de mercadorias que visam satisfazer as necessidades da população, sejam elas básicas de sobrevivência ou criadas pelos meios de comunicação e de informação. $\mathrm{O}$ consumo invade o cotidiano e direciona o comportamento das pessoas

1 Doutora em Geografia pela Universidade Estadual Paulista "Júlio de Mesquita Filho" (Unesp) e Professora Associada da Universidade Federal de Uberlândia (UFU). 
Consumption invades everyday life and affects people's behavior with an idealized concept that the purchasing of objects can lead one to happiness. With that renewed meaning, happiness has been turned into a good, acquired social value and invaded the lives of citizens, promoting changes in their habits and lifestyles and in the urban space.

The need of consumption has led to the specialization of exchanging activities, mainly in retail trade, with the concentration and centralization of enterprises which, in search of competition and monopoly, form commercial networks. As the place of social reproduction and of the commercial capital, the city is shaped by new tertiary forms that organize, reorganize, (dis)organize the structure of cities.

Many current forms of trade, like shopping malls and hypermarkets, have become locations for spectacles and temples for marketing goods. For many persons, going shopping is a moment of leisure and entertainment. That extrapolates the value based on the use and the value of exchange of goods.

With the transformations in the world of production and labor, goods move in international markets at a much higher speed, having become more global and caused important changes in the space of trade. So, the action of the capital and its agents on the territories is also geopolitical, for it creates power of decision and of implementation of commercial enterprises from social actions, standardizing and implementing new forms of control, of ruling and regulation of the productive restructuring of capital.

In order to meet the interests of transnational groups that need to build global spaces controlled by networks headquartered in many territories integrated, ruled and controlled by the capital, different commercial transactions made hegemonic by the financial capital have appeared. In global exchanges, the spaces of production, without defined frontiers, face nations that try to establish themselves against the reproduction of capital imposed by global enterprises. That process expresses the spatial formatting of the transnational capital dominance.

In a scenario of changes, of economic and social contradictions, there are forms of exchange established mainly at international level. They transcend frontiers and turn places for the exchange of products into spaces consumed as goods. The space of cities is also consumed by commercial structures that, in turn, attribute a value to the locations and give new meanings to them. 
idealizando que a felicidade será encontrada na aquisição de objetos. Com novo significado, a felicidade tornou-se mercadoria, adquiriu valor social, invadia a vida do cidadão promovendo mudanças nos hábitos, no estilo de vida e nos espaços urbanos.

A necessidade de consumo levou à especialização das atividades de troca, especialmente do comércio varejista com a concentração e a centralização de empresas que, na busca de competição e monopólio, formam redes comerciais. Como lugar da reprodução social e do capital comercial, a cidade é moldada pelas novas formas terciárias que organizam, reorganizam, (des)estruturam as cidades.

Muitas formas de comércio da atualidade, a exemplo dos shoppings centers e hipermercados, transformaram-se em espaços de espetáculos, em templos da mercadoria. Para muitas pessoas fazer compras significa um momento de descontração e entretenimento. Extrapola-se assim, o valor de uso e o valor de troca da mercadoria.

Com as transformações no mundo da produção e do trabalho, as mercadorias circulam em mercados globais com uma velocidade muito maior, tornaram-se globalizadas e provocaram importantes mudanças no espaço do comércio. Assim, ação do capital e de seus agentes sobre os territórios é também geopolítica, pois cria poder de decisão e de implantação de empreendimentos comerciais mediante ações sociais, padronizando e implementando novas formas de controle, de comando e regulação e de reestruturação produtiva do capital.

Para atender o interesse dos grupos transnacionais surgiram diferentes transações comerciais hegemonizadas pelo capital financeiro que precisam construir espaços globalizados, controlados por redes sediadas em vários territórios, integrados, comandados e controlados pelo capital. Nas trocas globais, os espaços de produção, sem fronteiras definidas, depararam-se com nações que tentam impor-se à reprodução do capital imposta pelas empresas globais. Este processo expressa a formatação espacial do domínio do capital transnacional.

Num cenário de mudanças, de contradições econômicas e sociais, surgem formas de trocas que se estabelecem espacialmente em nível mundial. Transcendem as fronteiras e transformam o local de troca de produtos em espaços que são consumidos como mercadoria. $O$ espaço das cidades também passa a ser consumido pelas estruturas comerciais que, por sua vez, atribuem valor ao lugar concedendoIhe novos significados.

Ao examinar a atividade comercial há que se ressaltar que a mesma se apresenta composta pelo comércio varejista e o atacadista. $O$ comércio varejista é representado pelos supermercados, hipermercados, shopping centers, lojas de departamento, 
When examining trade activity one should highlight that it consists of retail and wholesale trade. Retail is represented by supermarkets, hypermarkets, shopping malls, department stores, fairs, markets, vehicle concessionaires and other establishments characterized by the direct selling to consumers, usually in small amounts. Wholesale, on the other hand, is characterized by the commercialization of goods to registered legal persons such as institutions, restaurants, enterprises and retail trade establishments.

The Brazilian Institute of Geography and Statistics (IBGE) defines wholesale trade as that which sells goods to users that will manufacture, resell or incorporate them as a physical asset. It is responsible for intermediating sales between producers and retail resellers (PESQUISA..., 2016).

According to the Brazilian Association of Wholesalers and Distributors of Manufactured Products (ABAD), wholesale trade in Brazil comprises three dimensions: wholesale-distributor, which trades goods and has the function of delivering them to clients; cash and carry wholesaler, in which the client goes to an establishment, chooses the products and carries them to their establishment; and over-the-counter wholesaler, the most traditional type of all, in which a salesperson helps the customer in a wholesale establishment.

Considering the conceptual and theoretical reflections presented, the quantification of data on the trade sector reveals the dynamics of that activity as well as its importance to society, to cities and to the Brazilian economy.

The Annual Survey of Trade (PAC), conducted in 2016 by the IBGE, shows there were 1,546,546 commercial enterprises in the country that year. Among those, 1,205,003 enterprises were listed as retailers (74.07\% of the total), 195,304 belonged to wholesale trade $(17.23 \%)$ and 146,339 were traders of vehicles, pieces and motorcycles ( $8.7 \%$ of the total), as shown in Table 14.1. The data also show a predominance of retail establishments. Retail and automotive establishments, together, amounted to $83 \%$ of the trade establishments.

Concerning the participation of segments in the total revenue of retail trade and vehicles, presented in Graph 14.1, figures show that $23.2 \%$ of the revenues had been generated by the cash and carry food sector represented by supermarkets and hypermarkets; $17.6 \%$ by vehicles and pieces; $14.2 \%$ by trade of fuels; $8.6 \%$ by department, household appliances and furniture stores; $8.1 \%$ of the establishments corresponded to warehouses, grocery stores and food products 
feiras, mercados, concessionárias de veículos e outros, que se caracterizam pela venda direta ao consumidor, geralmente em pequena quantidade. Enquanto que $o$ comércio atacadista é aquele que desempenha a função de comercialização destinada, principalmente, a pessoas jurídicas que possuam cadastro de pessoa jurídica como instituições, restaurantes empresas e estabelecimentos comerciantes de varejo.

O Instituto Brasileiro de Geografia e Estatística (IBGE) define o comércio atacadista como aquele que revende mercadorias a usuários que as transformarão, revenderão ou incorporarão ao ativo fixo. Aquele que intermedia vendas entre produtores e revendedores varejistas (PESQUISA..., 2016).

De acordo com a Associação Brasileira de Atacadistas e Distribuidores de Produtos Industrializados (ABAD), o comércio atacadista do Brasil comporta três modalidades: 0 atacado-distribuidor, que comercializa a mercadoria e também assume a função de entregá-la ao cliente; o atacado de autosserviço no qual o cliente vai até o estabelecimento, serve-se dos produtos e os transporta até o seu estabelecimento; e o atacado de balcão, mais tradicional de todos, em que o cliente é atendido pelo vendedor no estabelecimento atacadista.

A partir das reflexões teórico-conceituais apresentadas, a quantificação de dados sobre o setor comercial revela a dinâmica desta atividade bem como a sua importância para a sociedade, para as cidades e para a economia brasileira.

A Pesquisa Anual de Comércio (PAC), realizada em 2016 pelo IBGE, demonstra que naquele ano existiam 1546546 empresas comerciais no País. Destas, 1205003 foram cadastradas como varejistas (representando 74,07\% do total), 195304 pertenciam ao comércio atacadista (17,23\%) e 146339 por empreendimentos que comercializavam veículos, peças e motocicletas (correspondendo a $8,7 \%$ do total), conforme demonstrado na Tabela 14.1. Os dados revelam ainda o predomínio de estabelecimentos de varejo. Somando-se os estabelecimentos varejistas com os automotivos chega-se a $83 \%$ dos estabelecimentos de comércio.

Ao observar a participação dos segmentos na receita total do comércio varejista e de veículos, apresentada no Gráfico 14.1 , os números demostram que $23,2 \%$ das receitas foram geradas pelo setor de autosserviço alimentar representados pelos supermercados e hipermercados; $17,6 \%$ por veículos e peças; $14,2 \%$ na comercialização de combustíveis; $8,6 \%$ lojas de departamento, eletrodomésticos e móveis; $8,1 \%$ dos estabelecimentos correspondiam a armazéns, mercearias e produtos alimentícios; $7,7 \%$ ao setor farmacêutico; $7,3 \%$ da receita foi gerada pela comercialização de tecidos e artigos do vestuário. 
shops: $7.7 \%$ to the pharmaceutical sector; $7.3 \%$ of the revenue was generated by the trade of fabric and wearing apparel.

In this scenario, putting together the participation of supermarkets, hypermarkets, and grocery stores, it is possible to state that they accounted for the generation of $31.8 \%$ of the revenue of the sector. It is worth highlighting that the big commercial centers hold a spatial and economic monopoly, as they trade several products in one same place. The diversity of items on sale goes beyond food products: wearing apparel, automotive products, household items, electronic items and others are also included.

The hegemony of sales imposed by those network-enterprises has taken place since their establishment in the country, after the second half of the 20th century, a period marked by the internationalization of the sector. In that period, the Brazilian consumer market, according to data from the IBGE, had 206 million inhabitants, being a major market to be supplied. Despite the reduction of sales in the period due to the deceleration of the market, the sector remained as the leader in retail trade.

With reference to the number of enterprises, employed persons and total net revenue and net sales revenue, the data presented in Tables 14.2 e 14.3 highlight the importance of retail trade which, in 2016 , had an overall revenue of $\mathrm{R} \$ 1,509$ billion reais; net sales revenue of $45.1 \%$ in the sector; employed $7,429,558$ workers $(74.1 \%)$ who performed their activities in 1,205,003 enterprises (77.9\%), and whose wages amounted to approximately $\mathrm{R} \$ 138.724$ billion reais $(64.6 \%)$.

In the same period, the total wholesale trade revenue was $\mathrm{R} \$ 1,546.972$ billion reais; $45.3 \%$ of the net sales revenue. Data also show the sector had 195,304 enterprises (12.6\%), employed 1,728,820 persons $(17.2 \%$ of the total), whose wages amounted to $\mathrm{R} \$ 56$ billion reais ( $25.9 \%)$. The data on trade of vehicles, pieces and motorcycles indicate it had a revenue of $\mathrm{R} \$ 323,414$ million reais; net revenue of sales of $9.6 \%$; with a total 146,339 enterprises $(9.5 \%)$ that employed 871,756 persons $(8.7 \%)$ and wages amounting to $\mathrm{R} \$ 20$ billion reais (9.5\%). In Brazil, most trade enterprises are in the retail sector; nevertheless, wholesale trade is bigger in terms of the revenue generated.

As for the total amount generated by both segments, considering the total revenue of approximately $\mathrm{R} \$ 3.4$ billion, it is worth highlighting that wholesale trade accounted for $\mathrm{R} \$ 1.547$ billion, retail trade, for $\mathrm{R} \$ 1.510$ billion and the automotive sector for $\mathrm{R} \$ 323$ million. Graph 
Nesse cenário, somando-se a participação dos supermercados, hipermercados, armazéns e mercearias, pode-se aferir que estes foram responsáveis pela geração de $31,8 \%$ das receitas do setor. Há que se salientar que as grandes superfícies comerciais exercem monopólio econômico e espacial, comercializando vários produtos no mesmo lugar. A diversidade de itens colocados à venda vai além dos voltados para a alimentação, inclui artigos de vestuário, produtos automotivos, eletrodomésticos, eletrônicos e outros.

A hegemonia de vendas imposta por estas empresas-rede ocorre desde sua implantação no País, a partir da segunda metade do Século XX, marcada pela internacionalização do setor. Naquele período, o mercado consumidor brasileiro, de acordo com os dados do IBGE, contava com 206 milhões de habitantes, constituindo um grande mercado para abastecer. Apesar do recuo nas vendas no período devido o desaquecimento do mercado, o setor manteve-se na liderança do varejo.

No que se refere ao número de empresas, pessoal ocupado e receita líquida total e receita líquida de revenda, as informações apresentadas nas Tabelas 14.2 e 14.3 reforçam a importância do comércio varejista que, no ano de 2016, obteve receita total de R\$ 1509 bilhões de reais; receita líquida de revende de 45,1\% no setor; empregava 7429558 trabalhadores (74,1\%) os quais exerciam suas atividades laborais em 1205003 empresas (77,9\%), cujos salários correspondiam a aproximadamente $\mathrm{R} \$ 138724$ bilhões de reais $(64,6 \%)$.

No mesmo período, considerando as mesmas informações, pode-se aferir que a receita total do comércio atacadista foi de R\$ 1546972 bilhões de reais; 45,3\% da receita líquida de revenda. Os dados revelam ainda que o setor possuía 195304 empresas (12,6\%), empregava 1728820 trabalhadores (17,2\% do total) que no conjunto receberam remunerações equivalente a $\mathrm{R} \$ 56$ bilhões de reais $(25,9 \%)$. Para o comércio de veículos, peças e motocicletas os dados informam que o mesmo gerou receita no valor de R\$ 323414 milhões de reais; um valor líquido de revenda no total de 9,6\%; com um total de 146339 empresas (9,5\%) que empregavam 871756 trabalhadores (8,7\%); somados os salários deste pessoal ocupado chegaram a $\mathrm{R} \$ 20$ bilhões de reais $(9,5 \%)$. Há no Brasil um número maior de empresas de varejo. Contudo, no que concerne à renda gerada, o comércio atacadista supera o valor gerado pelo varejo.

Com relação ao valor total gerado pelo conjunto, em relação à receita total que chegou a aproximadamente $\mathrm{R} \$ 3,4$ bilhões, destaca-se que o comércio atacadista foi responsável pelo faturamento de R\$ 1547 bilhões, o varejista R\$ 1510 bilhões e o setor automotivo por R\$323 milhões. O Gráfico 14.2 apresenta dados que justificam a participação do setor atacadista no que concerne a receita total do setor e revelam que 
14.2 presents data that justify the participation of the wholesale segment in terms of the overall revenue of the sector and show that $24 \%$ of the overall revenue was generated by the segment of fuels; $19.4 \%$ by the trade of food products, $11.7 \%$ by goods in general; $10.7 \%$ by pharmaceuticals; $7.8 \%$ by fresh agricultural products; $5 \%$ by machinery and equipment; and $21.3 \%$ by other products. The data reveal the diversity of products traded by wholesale enterprises.

With reference to the participation of enterprises by ranges of employed persons, Graph 14.3, shows there were 3,263,067.402 persons employed in the trade sector in 2016. The biggest enterprises, with 500 or more employees, corresponded to 1,040,638. 973 (31.9\%). The small ones, which employed up to 19 persons, were 927,143. 581 (28.9\%); those employing 20 to 29 persons, made up a total of $420,694.509$ (12.9\%); enterprises employing 50 to 99 persons were $281,444.433$ ones (8.6\%); a total of $365,924.442$ trade employees worked in enterprises that had between 100 and 249 persons employed (11.2\%); and the ones with 250 to 499 persons had, together, 227,221.464 employees (7.0\%)

With regard to the net operating revenue, the data in Graphs 14.4 and 14.5 , respectively, show that the enterprises with more than 500 employees accounted for a generated net revenue of $R \$ 1,040,638,973$. Enterprises that employed up to 19 workers were also a highlight in terms of net revenue, a total of $\mathrm{R} \$ 927,143,581$.

Graph 14.5 shows, in accordance with the aforementioned data, the generation of net operating revenue in the trade sector. It is observed that enterprises with up to 19 employees held $53.7 \%$ of the trade workers. Together with those enterprises that employed up to 49 persons, the percentage increases to $66 \%$. Small enterprises were responsible for the generation of a big number of positions. An explanation to that includes the transformations experienced by the production sector and the increase in the number of small-sized enterprises. Commercial automation, changes in the world of labor, due to outsourcing and subcontracting, for example, have led to a reduction of the number of jobs in big-sized enterprises since these transferred to others some parts of production and services. Many smaller enterprises now are in charge of the production process previously carried out by the big ones.

In this changing scenario, the tertiary sector has tried to adapt to a social behavior marked by new habits and lifestyles. That reinforces the idea that a market designed for the consumption of goods and services is a major guide of the economy, as revealed by the figures presented herein. 
$24 \%$ da receita total foi gerada pelo segmento de combustíveis; $19,4 \%$ pela comercialização de produtos alimentícios, $11,7 \%$ por mercadorias em geral; $10,7 \%$ por produtos farmacêuticos; $7,8 \%$ por produtos agropecuários in natura; $5 \%$ representado por máquinas e equipamentos e; $21,3 \%$ por outros produtos. Os dados demonstram diversidade de produtos comercializados através das empresas atacadistas.

Ao averiguar a participação das empresas por faixa de pessoal ocupado, Gráfico 14.3, em 2016 havia 3263067402 pessoas trabalhando no setor de comércio. As maiores empresas, que empregavam quinhentos ou mais pessoas, correspondiam a 1040638973 (31,9\%). As pequenas empresas que ocupavam até 19 funcionários geraram 927143581 empregos (28,9\%); as que empregavam de 20 a 29 pessoas, totalizaram 420694509 (12,9\%); as que empregavam de 50 a 99 trabalhadores absorviam 281444433 pessoas (8,6\%); 365924442 comerciários estavam empregados em empresas que possuíam de cem a 249 funcionários (11,2\%); e, as que empregavam de 250 a 499 pessoas somavam 227221464 trabalhadores (7,0\%)

Com relação à receita operacional líquida, os dados dos Gráficos 14.4 e 14.5 evidenciam que, de modo geral, as empresas que possuíam mais de 500 funcionários foram responsáveis pela geração de renda líquida de R\$ 1040638 973. As que empregavam até 19 trabalhadores também se destacaram com a geração de renda líquida, total de R\$ 927143581.

Corroborando com estes dados, o Gráfico 14.5 apresenta a geração de renda operacional líquida no setor comercial. Observa-se que as empresas que possuíam até 19 funcionários absorviam $53,7 \%$ dos trabalhadores do comércio. Somada às que empregavam até 49 funcionários, o percentual aumenta para $66 \%$. As pequenas empresas foram responsáveis pela geração de grande número de postos de trabalho. Tal fato pode ser explicado pelo processo de transformação no sistema produtivo e pelo aumento do número de pequenas empresas. A automação comercial, as transformações no mundo do trabalho, a exemplo da terceirização e da subcontratação, reduziram os postos de trabalho em grandes empresas que repassaram a pequenas partes da produção e dos serviços. Surgiram várias empresas menores que realizam parcela significativa do processo produtivo gerado anteriormente pelas grandes.

Neste cenário de mudanças o setor terciário tem procurado se adequar ao comportamento social marcado por novos hábitos e estilos de vida. O que reforça a ideia de que o mercado criado para o consumo de bens e serviços constitui um importante condutor da economia, fato revelado pelos dados quantitativos apresentados. 


\section{References}

CLEPS, G. D. G. O comércio atacadista de Uberlândia (MG): mudanças tecnológicas e estratégias territoriais. 1997. Dissertação (mestrado) - Instituto de Geociências e Ciências Exatas (IGCE), Universidade Estadual Paulista "Júlio de Mesquita Filho" (Unesp), Rio Claro. 1997. 180 f. 1997.

O comércio e a cidade: novas territorialidades urbanas. Sociedade \& Natureza, Uberlândia, v. 16, n. 30, p. 117-132, 2004. Available from: <http://www.seer.ufu.br/index.php/sociedadenatureza/issue/ archive/2>. Cited: May 2019.

Estratégias de reprodução do capital e as novas espacialidades urbanas: O comércio de auto-serviço em Uberlândia (MG). 2005. Tese (doutorado) - Instituto de Geociências e Ciências Exatas (IGCE), Universidade Estadual Paulista "Júlio de Mesquita Filho" (Unesp), Rio Claro. 2005. 317 f. Available from: <https://repositorio.unesp.br/bitstream/ handle/11449/104335/cleps_gdg_dr_rcla.pdf?seq>. Cited: May 2019.

NÚMEROS do setor. São Paulo: Associação Brasileira de Atacadistas e Distribuidores de Produtos Industrializados - ABAD, [2019]. Available from: <https://abad.com.br/servicos/dados-do-setor/>. Cited: May 2019.

PESQUISA ANUAL DE COMÉRCIO. Rio de Janeiro: IBGE, 2016.v. 26. Available from: <https://www.ibge.gov.br/estatisticas/economicas/comercio/9075pesquisa-anual-de-comercio.html?=\&t=o-que-e>. Cited: May 2019.

Translated by: Aline Milani Romeiro Pereira 


\section{Referências}

CLEPS, G. D. G. O comércio atacadista de Uberlândia (MG): mudanças tecnológicas e estratégias territoriais. 1997. Dissertação (mestrado) - Instituto de Geociências e Ciências Exatas (IGCE), Universidade Estadual Paulista "Júlio de Mesquita Filho" (Unesp), Rio Claro. 1997. 180 f. 1997.

- O comércio e a cidade: novas territorialidades urbanas. Sociedade \& Natureza, Uberlândia, v. 16, n. 30, p. 117-132, 2004. Disponível em: <http://www. seer.ufu.br/index.php/sociedadenatureza/issue/archive/2>. Acesso em: maio 2019.

. Estratégias de reprodução do capital e as novas espacialidades urbanas:

O comércio de auto-serviço em Uberlândia (MG). 2005. Tese (doutorado) - Instituto de Geociências e Ciências Exatas (IGCE), Universidade Estadual Paulista "Júlio de Mesquita Filho" (Unesp), Rio Claro. 2005. 317 f. Disponível em: <https://repositorio.unesp.br/ bitstream/handle/11449/104335/cleps_gdg_dr_rcla.pdf?seq>. Acesso em: maio 2019.

NÚMEROS do setor. São Paulo: Associação Brasileira de Atacadistas e Distribuidores de Produtos Industrializados - ABAD, [2019]. Disponível em: <https://abad.com.br/ servicos/dados-do-setor/>. Acesso em: maio 2019.

PESQUISA ANUAL DE COMÉRCIO. Rio de Janeiro: IBGE, 2016. v. 26. Disponível em: $<$ https://www.ibge.gov.br/estatisticas/economicas/comercio/9075-pesquisa-anualde-comercio.html?=\&t=o-que-e $>$. Acesso em: maio 2019. 
Tabela 14.1 - Dados gerais do comércio - 2016

Table 14.1 - General data of trade - 2016

\begin{tabular}{|c|c|c|c|c|}
\hline \multirow[b]{2}{*}{$\begin{array}{l}\text { Dados gerais/ } \\
\text { General data }\end{array}$} & \multicolumn{4}{|c|}{ Comércio/Trade } \\
\hline & $\begin{array}{l}\text { Total/ } \\
\text { Total }\end{array}$ & $\begin{array}{c}\text { Veículos, } \\
\text { peças e } \\
\text { motocicletas/ } \\
\text { Vehicles, } \\
\text { pieces and } \\
\text { motorcycles }\end{array}$ & $\begin{array}{l}\text { Atacadista/ } \\
\text { Wholesale }\end{array}$ & $\begin{array}{l}\text { Varejista/ } \\
\text { Retail }\end{array}$ \\
\hline $\begin{array}{l}\text { Número de empresas/ } \\
\text { Number of companies }\end{array}$ & 1546646 & 146339 & 195304 & 1205003 \\
\hline $\begin{array}{l}\text { Unidades locais com receita } \\
\text { de revenda/ } \\
\text { Local branches with revenue } \\
\text { from sales }\end{array}$ & 1685096 & 159175 & 217233 & 1308688 \\
\hline $\begin{array}{l}\text { Receita líquida de revenda } \\
(1000 \mathrm{R} \$) / \\
\text { Net revenue from } \\
\text { sales }(1,000 \mathrm{R} \$)\end{array}$ & 3263067402 & 313684171 & 1477918858 & 1471464373 \\
\hline $\begin{array}{l}\text { Pessoal ocupado/ } \\
\text { Employed persons }\end{array}$ & 10030152 & 871765 & 1728829 & 7429558 \\
\hline $\begin{array}{l}\text { Salários e retiradas } \\
(1000 \mathrm{R} \$) /\end{array}$ & 214793082 & 20492447 & 55576499 & 138724136 \\
\hline $\begin{array}{l}\text { Salaries and withdrawals } \\
(1,000 R \$)\end{array}$ & & & & \\
\hline
\end{tabular}

Fonte/Source: Pesquisa anual de comércio 2016. Rio de Janeiro: IBGE, v. 28, 2018. Disponível em/ Available from: <https://www.ibge.gov.br/estatisticas-novoportal/economicas/comercio/9075pesquisa-anual-de-comercio.html>.Acesso em: jan. 2019/Cited: Jan. 2019. 


\section{Tabela 14.2 - Número de empresas, pessoal ocupado, salários e receita total, segundo as divisões do comércio - 2016 Table 14.2 - Number of companies, employed persons, salaries and total revenue, by trade segments - 2016}

\begin{tabular}{|c|c|c|c|c|}
\hline $\begin{array}{l}\text { Divisões do comércio/ } \\
\text { Trade segments }\end{array}$ & $\begin{array}{l}\text { Número } \\
\text { de empresas/ } \\
\text { Number of } \\
\text { companies }\end{array}$ & $\begin{array}{l}\text { Pessoal } \\
\text { ocupado } \\
(1000) / \\
\text { Employed } \\
\text { persons } \\
(1,000)\end{array}$ & $\begin{array}{c}\text { Salários, retiradas } \\
\text { e outras remunerações } \\
\text { (bilhões } \mathrm{R} \$ \text { )/ } \\
\text { Salaries, withdrawals } \\
\text { and other compen- } \\
\text { sation (billions } R \$ \text { ) }\end{array}$ & $\begin{array}{c}\text { Receita total } \\
\text { (bilhões R\$)/ } \\
\text { Total revenue } \\
\text { (billions } R \$ \text { ) }\end{array}$ \\
\hline Total/ Total & 1546646 & 10030 & 215 & 3380 \\
\hline $\begin{array}{l}\text { Comércio de veículos, } \\
\text { peças e motocicletas/ } \\
\text { Sale of vehicles, pieces and } \\
\text { motorcycles }\end{array}$ & 146339 & 872 & 20 & 323 \\
\hline $\begin{array}{l}\text { Comércio atacadista/ } \\
\text { Wholesale trade }\end{array}$ & 195304 & 1729 & 56 & 1547 \\
\hline $\begin{array}{l}\text { Comércio varejista } \\
\text { Retail trade }\end{array}$ & 1205003 & 7430 & 139 & 1510 \\
\hline
\end{tabular}

Fonte/Source: Pesquisa anual de comércio 2016. Rio de Janeiro: IBGE, v. 28, 2018. Disponível em/ Available from: <https://www.ibge.gov.br/estatisticas-novoportal/economicas/comercio/9075pesquisa-anual-de-comercio.html>. Acesso em: jan. 2019/Cited: Jan . 2019.

\section{Tabela 14.3 - Participação das divisões do comércio - 2016 Table 14.3 - Participation of trade segments - 2016}

\begin{tabular}{|c|c|c|c|c|}
\hline \multirow[b]{2}{*}{$\begin{array}{l}\text { Divisões do comércio/ } \\
\text { Trade segments }\end{array}$} & \multicolumn{4}{|c|}{ Participação (\%)/ Participation (\%) } \\
\hline & $\begin{array}{c}\text { Número } \\
\text { de empresas/ } \\
\text { Number } \\
\text { of companies }\end{array}$ & $\begin{array}{l}\text { Pessoal } \\
\text { ocupado/ } \\
\text { Employed } \\
\text { persons }\end{array}$ & $\begin{array}{l}\text { Salários e outras } \\
\text { remunerações/ } \\
\text { Salaries and other } \\
\text { compensation }\end{array}$ & $\begin{array}{c}\text { Receita líquida } \\
\text { de revenda/ } \\
\text { Net revenue from } \\
\text { sales }\end{array}$ \\
\hline Total/ Total & 100,0 & 100,0 & 100,0 & 100,0 \\
\hline $\begin{array}{l}\text { Comércio de veículos, peças } \\
\text { e motocicletas/ } \\
\text { Sale of vehicles, pieces and } \\
\text { motorcycles }\end{array}$ & 9,5 & 8,7 & 9,5 & 9,6 \\
\hline $\begin{array}{l}\text { Comércio atacadista/ } \\
\text { Wholesale trade }\end{array}$ & 12,6 & 17,2 & 25,9 & 45,3 \\
\hline $\begin{array}{l}\text { Comércio varejista } \\
\text { Retail trade }\end{array}$ & 77,9 & 74,1 & 64,6 & 45,1 \\
\hline
\end{tabular}

Fonte/Source: IBGE, Diretoria de Pesquisas, Coordenação de Serviços e Comércio, Pesquisa Anual de Comércio 2016. 


\section{Gráfico 14.1 - Participação dos segmentos na receita total do comércio varejista e de veículos - Brasil - 2016 \\ Graph 14.1 - Participation of segments in total revenue of retail and vehicle trade - Brazil - 2016}

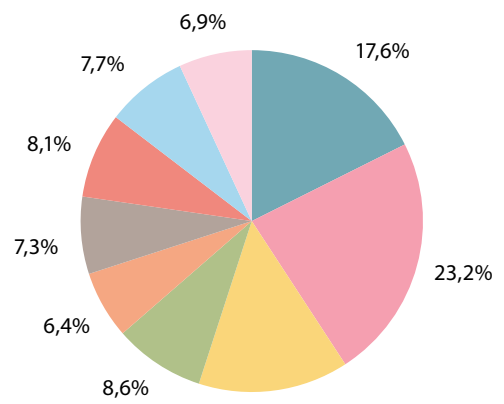

$14,2 \%$

Veículos e peças

Vehicles and pieces

Lojas de departamento, eletrodomésticos e móveis Department, household appliances and furniture stores

Armazéns, mercearias e produtos alimentícios Stores, grocery stores and food products
Super/Hipermercados

Supermarkets/Hypermarkets

Material de construção

Construction material

Produtos farmacêuticos

Pharmaceuticals
Combustíveis

Fuels

Tecidos e artigos do vestuário Textiles and wearing apparel

Outros

Other

Fonte/Source: IBGE, Diretoria de Pesquisas, Coordenação de Serviços e Comércio, Pesquisa Anual de Comércio 2016. 


\section{Gráfico 14.2 - Participação dos segmentos na receita total do comércio atacadista - Brasil - 2016 \\ Graph 14.2 - Participation of activities in total revenue of whosale trade - Brazil - 2016}

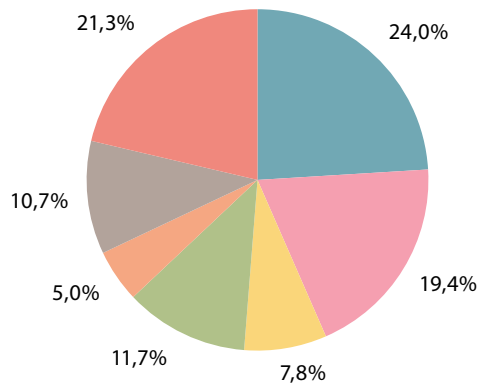

Combustíveis Fuels

Mercadorias em geral Miscellaneous goods
Produtos alimentícios, bebidas e fumo

Food products, beverages and tobacco
Produtos agropecuários in natura

Raw agricultural products
Máquinas e equipamentos industriais Industrial machinery and equipment
Produtos farmacêuticos Pharmaceuticals

Outros

Other

Fonte/Source: : IBGE, Diretoria de Pesquisas, Coordenação de Serviços e Comércio, Pesquisa Anual de Comércio 2016. 
Gráfico 14.3 - Participação das empresas, por faixas de pessoal ocupado, na receita operacional líquida do comércio - 2016

Graph 14.3 - Participation of companies, by ranges of employed persons, in net operating revenue of trade - 2016

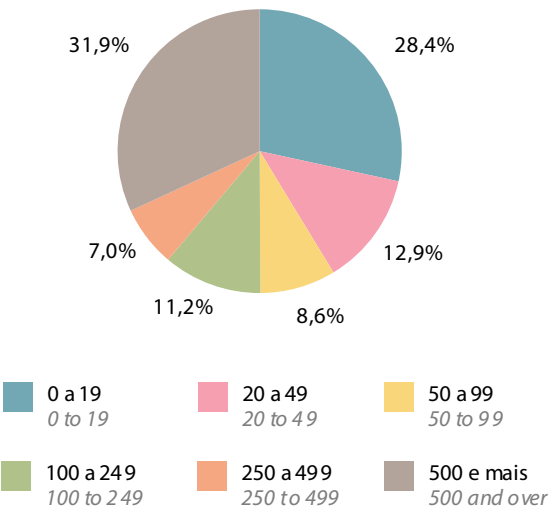

Fonte/Source: IBGE, Diretoria de Pesquisas, Coordenação de Serviços e Comércio, Pesquisa Anual de Comércio 2016.

\section{Gráfico 14. 4 - Evolução da receita operacional líquida, por faixas de pessoal ocupado - 2015-2016}

Graph 14.4 - Evolution of net operating revenue, by ranges of employed persons - 2015-2016

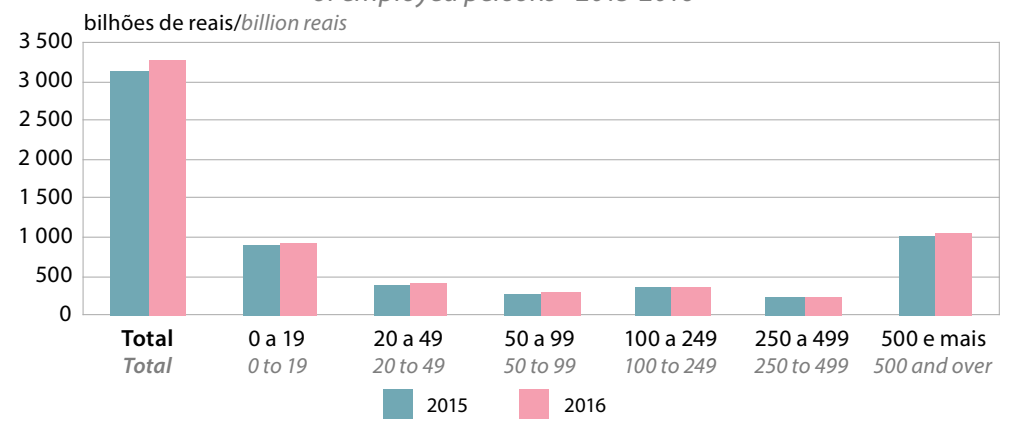

Fonte/Source: IBGE, Diretoria de Pesquisas, Coordenação de Serviços e Comércio, Pesquisa Anual de Comércio 2015-2016. 
Gráfico 14.5 - Participação das empresas, por faixas de pessoal ocupado, no total de pessoal ocupado do comércio - 2016

Graph 14.5 - Participation of companies in total employed persons in trade, by ranges of employed persons - 2016

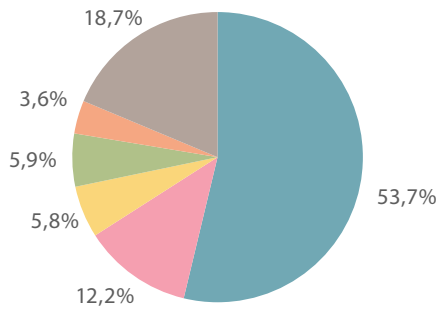

\begin{tabular}{|c|c|c|}
\hline 0 a 19 & 20 a 49 & 50 a 99 \\
\hline 0 to 19 & 20 to 49 & 50 to 99 \\
\hline 100 a 249 & 250 a 499 & 500 e mais \\
\hline 100 to 249 & 250 to 499 & 500 and over \\
\hline
\end{tabular}

Fonte/Source: IBGE, Diretoria de Pesquisas, Coordenação de Serviços e Comércio, Pesquisa Anual de Comércio 2016. 